University of New Hampshire

University of New Hampshire Scholars' Repository

$12-2015$

\title{
Mycorrhizal roots in a temperate forest take up organic nitrogen from 13C- and 15N-labeled organic matter
}

\author{
Matthew A. Vadeboncoeur \\ University of New Hampshire, matt.vad@unh.edu \\ Andrew P. Ouimette \\ University of New Hampshire \\ Erik A. Hobbie \\ University of New Hampshire
}

Follow this and additional works at: https://scholars.unh.edu/ersc

Part of the Biogeochemistry Commons, and the Forest Biology Commons

\section{Comments}

This is an Accepted Manuscript. The final publication is available at Springer via https://dx.doi.org/10.1007/

s11104-015-2623-1

\section{Recommended Citation}

Vadeboncoeur MA, Ouimette AP, Hobbie EA. 2015. Mycorrhizal roots in a temperate forest take up organic nitrogen from 13C- and 15N-labeled organic matter. Plant and Soil, 397:303-315. doi:10.1007/

s11104-015-2623-1

This Article is brought to you for free and open access by the Institute for the Study of Earth, Oceans, and Space (EOS) at University of New Hampshire Scholars' Repository. It has been accepted for inclusion in Earth Systems Research Center by an authorized administrator of University of New Hampshire Scholars' Repository. For more information, please contact Scholarly.Communication@unh.edu. 


\title{
Mycorrhizal roots in a temperate forest take up organic nitrogen from ${ }^{13} \mathrm{C}$ - and ${ }^{15} \mathrm{~N}$-labeled organic matter
}

Plant \& Soil (2015) 397: 303-315.

\author{
Matthew A. Vadeboncoeur \\ Andrew P. Ouimette \\ Erik A. Hobbie \\ Earth Systems Research Center \\ University of New Hampshire \\ 8 College Road, Durham, NH 03824 USA
}

This is a post-peer-review, pre-copyedit version of an article published in Plant \& Soil.

This document is shared in accordance with Springer's self-archiving policy.

The final authenticated version is available online at: http://dx.doi.org/10.1007/s11104-015-2623-1 


\section{Abstract \\ Background and Aims}

The importance of the uptake of nitrogen in organic form by plants and mycorrhizal fungi has been demonstrated in various ecosystems including temperate forests. However, in previous experiments, isotopically labeled amino acids were often added to soils in concentrations that may be higher than those normally available to roots and mycorrhizal hyphae in situ, and these high concentrations could contribute to exaggerated uptake.

\section{Methods}

We used an experimental approach in which we added ${ }^{13} \mathrm{C}$-labeled and ${ }^{15} \mathrm{~N}$-labeled whole cells to rootingrowth cores, allowing proteolytic enzymes to release labeled organic nitrogen at a natural rate, as roots and their associated mycorrhizal fungi grew into the cores. We employed this method in four forest types representing a gradient of soil $\mathrm{pH}$, nitrogen mineralization rate, and mycorrhizal type.

Results

Intact uptake of organic nitrogen was detected in mycorrhizal roots, and accounted for at least of 1-14\% of labeled nitrogen uptake. Forest types did not differ significantly in the importance of organic uptake.

\section{Conclusions}

The estimates of organic $\mathrm{N}$ uptake here using ${ }^{13} \mathrm{C}$-labeled and ${ }^{15} \mathrm{~N}$-labeled whole cells are less than those reported in other temperate forest studies using isotopically labelled amino acids, and likely represent a minimum estimate of organic N-use. The two approaches each have different assumptions, and when used in tandem should complement one another and provide upper and lower bounds of organic $\mathrm{N}$ use by plants.

Keywords: organic nitrogen uptake, ingrowth core, dual label, temperate forest

Abbreviations: AA - amino acid

DIN - dissolved organic nitrogen

$f_{\text {intact }}-$ fraction of $\mathrm{N}$ uptake in organic form 


\section{Introduction}

Primary production in forest ecosystems is often limited by nitrogen $(\mathrm{N})$ availability (LeBauer and Treseder 2008; Vadeboncoeur 2010; Harpole et al. 2011). Studies conducted in culture and in the field have demonstrated some degree of plant access to organic nitrogen in the soil across many different ecosystem types, which has been described as a "short-circuit" of the microbial mineralization "bottleneck" in the nitrogen cycle as it was traditionally understood (Chapin et al. 1993; Chapin et al. 2003; Näsholm et al. 2009). Organic nitrogen use in plants could be important to ecosystem productivity when soil temperature, moisture, litter quality, and secondary chemistry limit the rate of microbial nitrogen mineralization, such as in polar (Chapin et al. 1993; Hill et al. 2011a; Inselsbacher and Näsholm 2012), boreal (Näsholm et al. 1998; Persson et al. 2003; Mayor et al. 2012), alpine (Lipson et al.1999), and heathland ecosystems (Stribley and Read 1980; Paungfoo-Lonhienne et al. 2008). In temperate forests, the $\mathrm{N}$ economy was traditionally thought to be dominated by inorganic forms, but a number of studies have shown substantial uptake rates (Finzi and Berthrong 2005; Gallet-Budynek et al. 2009; Averill and Finzi 2011; Rothstein 2014).

Better understanding of organic $\mathrm{N}$ uptake is important in both community ecology and global change studies. Differential access to organic nitrogen among plant species or via mycorrhizal fungi play a role in determining plant community composition (McKane et al. 2002; Clark et al. 2005; Wurzburger and Hendrick 2009; Jacob and Leuschner 2015). Furthermore, competition of mycorrhizal fungi for organic nitrogen and the consequent nitrogen limitation of the saprotrophic microbial community may reduce overall decomposition rates and indirectly increase soil carbon storage (Orwin et al. 2011; Averill et al. 2014).

To measure organic $\mathrm{N}$ uptake in the field organic substrates (often glycine, but sometimes other amino acids or oligopeptides) labeled with ${ }^{13} \mathrm{C}$ and ${ }^{15} \mathrm{~N}$ are typically added to the soil, with roots harvested

for isotopic analysis after a period of hours. The ratio of ${ }^{13} \mathrm{C}$ excess to ${ }^{15} \mathrm{~N}$ excess in the roots is then used to apportion uptake of added $\mathrm{N}$ between intact organic uptake and uptake after mineralization. Studies which apply amino acids labeled only with ${ }^{15} \mathrm{~N}$ (e.g. Jacob and Leuschner 2015) cannot distinguish 
between direct uptake in organic form vs. uptake of inorganic $\mathrm{N}$ after microbial mineralization of the amino acid.

Such studies assume that the added label does not substantially change the available concentration of the substrate, and does not affect uptake kinetics (Kirkham and Bartholomew 1954; Blackburn and Knowles 1992). However, substantial doubt has been cast on methods commonly used to measure available amino acid concentrations in soils. Hobbie and Hobbie $(2012 ; 2013)$ argued that the large populations of bacteria in soils should maintain amino acid concentrations in the nanomolar range, while measured concentrations in soil are often orders of magnitude greater. They suggest that most of what is measured as available in soil extracts may be physically or chemically protected from absorption in situ. The difference is attributed to disturbance effects of soil sampling, which may be especially large in forest soils dominated by ectomycorrhizal species, due to high extraradical mycelium biomass in the soil (Jones et al. 2005a).

If labeled amino acid addition experiments violate the tracer assumption by substantially increasing free amino acid concentrations in soil solutions, then plants may be relatively more competitive with microbes for amino acids than under natural conditions (Jones et al. 2005b; Hobbie and Hobbie 2012). Such studies also implicitly assume that the added substrate(s) (most commonly glycine) are representative of other forms of organic nitrogen (e.g., all free amino acids) in their availability to plant roots or mycorrhizal fungi relative to free-living microbes. However, among amino acids, glycine may be both a poor carbon source for microbes due to its low ratio of $\mathrm{C}$ to $\mathrm{N}$, and more available to plants due to its high diffusion rate (Lipson et al. 1999; Lipson and Näsholm 2001). On the other hand, other forms of organic nitrogen such as oligopeptides and amino sugars may also be quantitatively important nitrogen sources to plants or mycorrhizal fungi (Hill et al. 2011b; Whiteside et al. 2012), so amino acid studies may miss important organic nitrogen fluxes (Xu et al. 2006).

Due to these shortcomings, the methods commonly used are insufficient to unequivocally demonstrate and quantify fluxes of organic versus inorganic nitrogen to plants in ecosystems. Additional complimentary experimental approaches that avoid the problematic assumptions discussed above, even 
while potentially making others, are required to gain a full understanding of the importance of organic $\mathrm{N}$ uptake. Here, we use an approach involving ${ }^{13} \mathrm{C}$-labeled and ${ }^{15} \mathrm{~N}$-labeled whole-cell substrate to quantify uptake of isotopically labeled organic nitrogen by tree roots or associated mycorrhizal fungi in four temperate forest types. We hypothesized that we would be able to detect intact organic $\mathrm{N}$ uptake with this method, and that sites with lower nitrogen mineralization rates would rely more on organic nitrogen than sites with greater mineralization rates.

Our approach is similar to that employed in an alpine meadow by Xu et al. (2006), and involves adding a double-labeled $\left({ }^{13} \mathrm{C}\right.$ and $\left.{ }^{15} \mathrm{~N}\right)$ whole-cell substrate to root ingrowth cores and incubating for several weeks. The added substrate is subject to natural rates of proteolysis and mineralization, while roots are growing in the cores. This approach avoids the need for potentially problematic measurements of the bioavailable concentrations of dissolved organic nitrogen compounds, and requires only that the tracer addition be small relative to the total organic matter pool available for proteolysis and mineralization. By employing root ingrowth cores, we ensure that the roots analyzed are a single cohort of actively growing fine roots, improving the potential to compare across sites and soil depths, and avoiding the difficult task of separating live from recently dead roots. This method requires several assumptions as well, chiefly regarding the suitability of ingrowth cores as a proxy for the intact soil environment, but is valuable as a complement to previous tracer and natural abundance isotope studies and should provide further constraints to estimates of organic $\mathrm{N}$ uptake in forest ecosystems.

\section{Methods}

\section{Site Description}

We selected forest stands representing a gradient of species composition, soil C:N ratios, $\mathrm{pH}$, and nitrogen mineralization rates in Strafford County, New Hampshire, USA (Table 1; Vadeboncoeur 2013). We selected two stands in each of four targeted species assemblages: (1) "maple" (Acer saccharum L. with some Fraxinus americana L.); (2) “oak-beech” (Quercus rubra L. and Fagus grandifolia Ehrh.); (3) “pine” (Pinus strobus L.); and (4) “spruce” (Picea rubens Sarg. with some Tsuga canadensis L.). All 
study sites were mature second-growth forest stands which had been at least partially cleared for grazing by the mid- $19^{\text {th }}$ century and abandoned by about 1930 . In the USDA soil classification system, soils were predominantly mapped as Inceptisols (Dystrudepts) developed in glacial till, except at site JP which was an Udorthent developed on sandy outwash. The soil profiles we examined occasionally included incipient eluviated horizons diagnostic of Spodosols (Haplorthods) at sites BJ, PS, and KF.

Root ingrowth cores were established in three replicate blocks in each stand. Block locations were selected for high local dominance of target species (ideally $>80 \%$ of basal area within $5 \mathrm{~m}$ of the cores) and a lack of obstructions or evidence of recent disturbance in the top $20 \mathrm{~cm}$ of the soil profile.

\section{Field Methods}

Ingrowth Core Establishment

In each of three replicate blocks per study stand, two cores $5.7 \mathrm{~cm}$ in diameter were taken to a depth of 10-12 cm after removal of the litter (Oi) layer. Core locations within a block were separated by $30-50 \mathrm{~cm}$. Each core was marked with three aluminum rods around its perimeter as guides for eventual re-coring. Soil removed from the ingrowth cores was gently sieved to $4.75 \mathrm{~mm}$, picked carefully for fine roots and litter, and mixed in approximately a 1:2 ratio with soil that had been previously collected from several exploratory cores at each site, air-dried, and sieved to $2 \mathrm{~mm}$. This was done to provide sufficient volume without an excessive amount of field sieving, which does not easily yield large volumes of rootfree soil. Soil horizons sampled were predominantly mineral horizons, except in the spruce sites (especially JB), where the top $10 \mathrm{~cm}$ was highly organic. Cores were covered with leaf litter at the surface to reduce drying and prevent erosion of the fill soil. Ingrowth cores were installed between 30 June and 3 July 2011 across the 8 sites.

\section{Substrate Addition}

Four weeks after establishment (2-4 August 2011), all sites were visited for pre-treatment soil sampling and label addition. A plug of soil $2 \mathrm{~cm}$ in diameter and $2 \mathrm{~cm}$ in depth was removed from each core for $\mathrm{pH}$ and $\mathrm{N}$ availability analysis and composited by block. The surface of the core was re-filled with reserved sieved soil. 
Each experimental replicate included a control core (no addition) and a paired core to which double-labeled organic nitrogen was added. To teach treated core, we injected $1 \mathrm{ml}$ of a suspension of ${ }^{13} \mathrm{C}$ and ${ }^{15} \mathrm{~N}$ universally-labeled cyanobacteria (Agmenellum quadruplicatum strain PR-6; Cambridge Isotope Labs, Andover, MA, USA), using a 5-hole template and a 22 gauge, $35 \mathrm{~mm}$ syringe needle. The labeled substrate contained approximately $2.5 \mathrm{mg} \mathrm{N}\left(98 \%{ }^{15} \mathrm{~N}\right)$, and $11.5 \mathrm{mg} \mathrm{C}\left(98 \%{ }^{13} \mathrm{C}\right)$ per core. The magnitude of label addition ranged from $0.3 \%$ to $0.5 \%$ of total soil organic $\mathrm{N}$.

\section{Core Harvesting}

Cores were harvested to a depth of $10 \mathrm{~cm}$ approximately 6 weeks after substrate addition (10-13 September 2011) with a sharpened PVC pipe $40.5 \mathrm{~mm}$ in inside diameter. Nitrile gloves were worn and changed between treatments for harvesting and for all lab processing steps. Separate corers were used for each isotope treatment and rinsed between sites. Any roots not fully cut and found protruding into the cored volume were collected carefully with scissors. Samples were stored at $4^{\circ} \mathrm{C}$ for up to 48 hours until processing.

\section{Laboratory Methods}

Roots were gently cleaned of soil in $1 \mathrm{mM} \mathrm{CaCl}_{2}$ and first-order through third-order roots of the target species separated from other roots. Root species was determined by gross morphology, branching pattern, color, and the presence of ectomycorrhizal fungi. Root samples were freeze-dried and weighed. Dried roots were examined at 20x magnification, rinsed and re-dried if necessary before further being subsampled with scissors (1-4 mg), for analysis on a Costech 4010 Elemental Analyzer coupled to a Delta Plus XP isotope ratio mass spectrometer. For a subset $(n=8)$ where sufficient sample was available, multiple fine root subsamples from the same core were analyzed. Enriched samples were run separately from control samples. To reduce isotopic carryover between enriched root samples, root analyses alternated with $\sim 5 \mathrm{mg}$ of a low $\mathrm{C}: \mathrm{N}$ natural-abundance reference material.

For a subset of treatment root samples with sufficient mass $(n=12)$, we extracted structural protein to more precisely measure its ${ }^{13} \mathrm{C}$ enrichment. Samples were first extracted with hexane to remove nonpolar compounds, then with isopropanol to remove soluble polar compounds, and finally with $6 \mathrm{M} \mathrm{HCl}$ at 
$110^{\circ} \mathrm{C}$ to hydrolyze non-soluble protein (Hobbie et al. 2013). Amino acids were purified from the hydrolysate on cation exchange resin (Dowex 50WX8) and analyzed on the IRMS in silver capsules. Three archived samples of homogenized unlabeled roots from the Bartlett Experimental Forest were extracted in the same way to examine the difference between bulk root $\delta^{13} \mathrm{C}$ and root protein $\delta^{13} \mathrm{C}$.

\section{Site and soil characterization data}

Soil plugs were stored in sealed bags at $4^{\circ} \mathrm{C}$ for up to 4 days before being picked through for roots and other litter and gently mixed. Because moisture content was low at the time of sampling and quite variable among samples, $3 \mathrm{ml}$ of distilled water was added to each sample and well mixed before further processing. A $5 \mathrm{~g}$ subsample of each was placed in a sealed polyethylene plastic bag to be incubated for 31 days in a dark cabinet at $\sim 20^{\circ} \mathrm{C}$, and a separate $5 \mathrm{~g}$ subsample was extracted for exchangeable ions in $50 \mathrm{ml}$ of $1 \mathrm{M} \mathrm{KCl}$. Three blank $\mathrm{KCl}$ solutions were run with each set (pre-incubation and postincubation). Concentrations of $\mathrm{NH}_{4}$ and $\mathrm{NO}_{3}$ were determined colorimetrically on an Astoria autoanalyzer. Separate subsamples of soil were oven-dried at $60^{\circ} \mathrm{C}$ to determine moisture content and then milled for $\mathrm{C}$ and $\mathrm{N}$ analysis. Core soil bulk density was estimated from \% $\mathrm{C}$ data based on the relationship published by (Federer et al. 1993) for sandy-loam till soils in New Hampshire. The remaining soil was pooled by block or site (as dictated by remaining sample mass) and $\mathrm{pH}$ was measured in a 1:2 solution with deionized water.

\section{Organic nitrogen uptake calculations}

For bulk root samples and the extracted amino acids, we calculated $f_{\text {intact }}$, the fraction of nitrogen label that was taken up as an intact organic molecule (i.e. with its associated labeled carbon), based on the ratio of excess ${ }^{13} \mathrm{C}$ to excess ${ }^{15} \mathrm{~N}$ in each sample. Excess was calculated as the difference in atom fraction of each heavy isotope from the baseline natural abundance (Coplen 2011).

Based on control samples, mean background root $\delta^{13} \mathrm{C}$ ranged from $-28.9 \%$ to $-26.2 \%$ across stands (Table 2). In the control sample roots, there was evidence of lateral transfer of $\mathrm{N}$ within root systems from ${ }^{15} \mathrm{~N}$ labeled cores to control cores; $\delta^{15} \mathrm{~N}$ ranged from $-2.8 \%$ o to $+34.7 \%$, with the high end of 
this range well beyond natural variability. Such unusually high root $\delta^{15} \mathrm{~N}$ values occurred across all forest types. Because of this, we used the pre-treatment soil $\delta^{15} \mathrm{~N}$ values for each site as the background value instead, since shallow roots closely track bulk soil $\delta^{15} \mathrm{~N}$ (Högberg et al. 1996; Ouimette et al. 2012). Site averages of bulk soil $\delta^{15} \mathrm{~N}$ ranged from $+0.3 \%$ to $+4.3 \%$ (Table 1 ). Due to the degree of isotopic enrichment in labeled root samples (Table 2), the calculations that follow are insensitive to uncertainties on the order of several per-mil in baseline $\delta^{15} \mathrm{~N}$, but more sensitive to variation in baseline $\delta^{13} \mathrm{C}$.

For bulk roots, we calculated protein-carbon concentration assuming that protein was the only source of measured bulk-root nitrogen, and that protein was $16 \% \mathrm{~N}$ and $45 \% \mathrm{C}$ by mass. We then calculated the molar ratio of ${ }^{15} \mathrm{~N}$ excess to ${ }^{13} \mathrm{C}$ excess in root protein, assuming that all labeled carbon occurred in protein. This ratio was then converted to a ratio of labeled amino acid (AA) uptake to total labeled nitrogen uptake, based on a molar C:N ratio of 3.34 in protein (Hobbie et al. 2012), and assuming that $50 \%$ of AA-carbon is respired on uptake; this estimate falls towards the high side of the range observed in microbial cultures (Hobbie and Hobbie 2012), and was chosen to allow for the possibility of respiration by both the fungal and plant symbionts. Calculation steps are detailed in Online Resource 1. The fraction of total labeled nitrogen uptake that occurred in organic form $\left(f_{\text {intact }}\right)$ was averaged by core (for the cores in which we analyzed multiple root samples) and then by site.

With protein extractions of root samples, we directly measured the $\delta^{15} \mathrm{~N}$ and $\delta^{13} \mathrm{C}$ of root protein, to provide a check on bulk-root estimates. For protein, we again assumed that baseline $\delta^{15} \mathrm{~N}$ was equal to that of the bulk soil, but that baseline $\delta^{13} \mathrm{C}$ was enriched by $2.1 \%$ relative to the mean $\delta^{13} \mathrm{C}$ of bulk roots from control cores at each site. Subsequent calculations proceeded as described above for bulk roots.

\section{Statistics and Uncertainty Analysis}

Metrics of organic $\mathrm{N}$ uptake were related to individual site characteristics including 0-10 $\mathrm{cm}$ soil $\% \mathrm{C}, \mathrm{C}: \mathrm{N}, \mathrm{pH}$, exchangeable $\mathrm{NH}_{4}{ }^{+}, \mathrm{N}$ mineralization, nitrification, and total root ingrowth mass with linear regression. Regressions were examined at both the site scale $(n=8)$ and the core scale $(n=23$; one 
core contained no target species roots). Differences in $f_{\text {intact }}$ and soil characteristics among sites were assessed with one-way ANOVAs.

In order to assess two of the larger potential sources of error in our calculation, we used a Monte Carlo approach (Yanai et al. 2012). The two sources of error we assessed were 1) uncertainty in sitemean control root $\delta^{13} \mathrm{C}$ and 2) the estimate of amino acid $\mathrm{C}$ lost to respiration or transamination in extraradical fungal tissue.

The error of our estimate of the mean $\delta^{13} \mathrm{C}$ of control roots at each site comes predominantly from sampling a variable population. We modeled control root $\delta^{13} \mathrm{C}$ as a normal distribution using the mean and standard deviation of control roots (Table 2), and generated 10,000 random values to carry through the calculation of intact organic uptake of the $\mathrm{N}$ label. Calculated ratios of organic:inorganic uptake of the $\mathrm{N}$ label scale linearly with the difference between the labeled sample and the corresponding control sample, and potential error was therefore symmetric and means were unchanged.

Another potential source of error is our estimation that $50 \%$ of amino acid C is respired or lost between uptake and our measurement of stable $\mathrm{C}$ isotope ratios in mycorrhizal fine roots (Hobbie and Hobbie 2012). Because this term appears in the denominator when calculating $f_{\text {intact }}$, the uncertainty associated with it is nonlinear, and scales as 1/(n-1) (Online Resource 1). We modeled the uncertainty in this parameter as a uniform distribution with a fairly wide range between 0.25 and 0.75 , based on data reviewed by Hobbie and Hobbie (2012), and the possibility that some amino acid C might be retained in unsampled extraradical parts of the mycorrhizal fungus. Uncertainty is reported based on the 2.5 and 97.5 percentiles of the Monte Carlo distribution for each site.

\section{Results}

\section{Soil differences among stand types}

Our data indicate large and statistically significant differences among study sites in soil pH, C:N, and organic matter percentage (Table 1, single-factor ANOVA $p$ values all <0.001). Spruce stand soils had the highest $\mathrm{C}: \mathrm{N}$ ratios and lowest $\mathrm{pH}$, while maple stand soils had the lowest $\mathrm{C}: \mathrm{N}$ and highest $\mathrm{pH}$; 
oak-beech and pine soils were intermediate. Spruce soils had by far the greatest concentrations of organic carbon (the top $10 \mathrm{~cm}$ was mostly or entirely in the Oa horizon where sampled), and maple soils had relatively thick and organic-rich A horizons relative to the oak-beech and pine soils. Bulk nitrogen concentrations were similar in spruce and maple soils, and greater than in oak-beech and pine soils. Exchangeable $\mathrm{NH}_{4}{ }^{+}$and potential $\mathrm{N}$ mineralization per gram of soil was greatest in the maple and spruce stands and lowest in the oak stands. However, because bulk density was estimated to be $35-50 \%$ lower in the spruce soils than at the other sites (Table 1), dissolved inorganic nitrogen (DIN) availability was greatest in the maple sites. Soils removed from the cores did not have detectable nitrate prior to the lab incubation. Net mineralization (including nitrate production) per g soil varied widely within a site, but significantly differed across stands $(n=8$; ANOVA $p=0.01)$ and across forest types $(n=4$; ANOVA $p=$ 0.02). In general, the maple ( $35 \pm 11 \mu \mathrm{g} \mathrm{N} \mathrm{g}{ }^{-1}$ soil) and oak-beech soils ( $23 \pm 20 \mu \mathrm{g} \mathrm{N} \mathrm{g}^{-1}$ soil $)$ had greater $\mathrm{N}$ mineralization than pine and spruce soils $\left(6 \pm 12\right.$ and $12 \pm 18 \mu \mathrm{g} \mathrm{N} \mathrm{g}^{-1}$ soil, respectively). In the lab incubation, net nitrification occurred in some replicates of incubated soils from all stand types and did not differ significantly by stand or forest type.

Root ingrowth mass of target species also varied significantly across the four stand types but not across core labeling treatments (Table 2; 2-way ANOVA $p<0.001$ and $p=0.50$, respectively). Oakbeech stands had the greatest root ingrowth, followed by maple. In the spruce stands our root isotopic analyses were sometimes quite sample-limited. These differences in root production are consistent with those observed over several years across a similar species gradient at the Bartlett Experimental Forest (Ouimette \& Vadeboncoeur; unpublished data).

\section{Uptake of organic nitrogen}

Across all study sites, organic uptake of labeled nitrogen averaged 5\% of total labeled nitrogen uptake; in individual cores it ranged from 0 to $50 \%$ (Figure 1). There was no significant difference by site or forest type (single-factor ANOVA $p=0.43$ and 0.12 , respectively), although the mean value for spruce stands $(16 \%)$ was notably greater than those of the other forest types, which averaged $2 \%$ to $4 \%$. 
Among all the site factors we examined, only soil \%C correlated significantly with uptake of labeled $\mathrm{N}$ in organic form $\left(p<0.01, r^{2}=0.27\right)$; these trend was driven largely by the higher mean organic $\mathrm{N}$ uptake observed at the spruce sites, where the top $10 \mathrm{~cm}$ was predominantly in the Oa horizon. Regressions against metrics of $\mathrm{N}$ availability based on the lab incubation were not significant (data not shown).

Amino acid extractions of roots yielded estimates of organic uptake of the ${ }^{15} \mathrm{~N}$ label in the same general range as those estimated from bulk roots (Figure 2). Overall, the two estimates across replicate cores were not significantly correlated. However, the two estimates were strongly correlated in oak-beech samples $\left(r^{2}=0.74 ; p=0.03\right)$ and agreed closely with the expected $1: 1$ relationship (Figure 2$)$. By contrast, for maple, pine, and spruce samples organic label uptake was greater in the bulk analyses than in the amino acid analyses (paired $t$-test, $\mathrm{p}<0.01$ ). Some of this variation likely reflects isotopic inhomogeneity within root samples; replicate analyses of 1-4 mg subsamples of non-homogenized bulk roots had coefficients of variation ranging from $20-115 \%$ in the ratio of ${ }^{13} \mathrm{C}$ excess to ${ }^{15} \mathrm{~N}$ excess.

\section{Uncertainty Analysis}

In the Monte Carlo analysis, the two sources of variation contributed about equally to variation in the resulting distribution. Uncertainty due to baseline $\delta^{13} \mathrm{C}$ measurements depended on the variation among replicate samples analyzed, the degree of enrichment in the labeled samples, and the C:N ratio of analyzed fine roots, (Figures 1 and 3). Variation in intact organic uptake estimated with the Monte Carlo analysis was generally large relative to the variability among replicate ingrowth cores, except at site PS (Figure 3). As mentioned previously, uncertainty in baseline $\delta^{15} \mathrm{~N}$ is of little consequence due to the level of ${ }^{15} \mathrm{~N}$ enrichment we observed. An uncertainty of even $4 \%$ in baseline $\delta^{15} \mathrm{~N}$ (the full range observed across all 8 sites), would only show up in the third significant figure of intact organic uptake for our leastenriched sample. 


\section{Discussion}

\section{Organic nitrogen uptake across sites}

Our results clearly indicate intact uptake of organic nitrogen compounds by fine roots or their associated mycorrhizal fungi. However, the contribution of these nitrogen forms to the total root nitrogen budget was generally small and highly variable at the fine spatial scale examined. Among stands, organic uptake did not correspond with the soil differences that we expected to correlate with differences in organic nitrogen use; there was not a significant correlation between lab mineralization rate and $f_{\text {intact }}$. However, spruce sites had a generally greater fraction of labeled uptake in organic form, as well as high C:N ratios and low $\mathrm{pH}$, which are normally associated with slow $\mathrm{N}$ cycling. Functional differences between microbial communities and types of organic matter present in the mineral vs. organic horizons may complicate the site comparisons between the spruce sites and the other forest types. However, fine roots in the soil horizons examined likely provide the bulk of $\mathrm{N}$ uptake in each stand.

\section{Methodological considerations}

\section{Advantages}

Our method bears similarities to the method employed by Xu et al. (2006) in that it involved the addition of double-labeled whole cells (though $\mathrm{Xu}$ et al. used ${ }^{14} \mathrm{C}$ rather than ${ }^{13} \mathrm{C}$ and intact cores rather than ingrowth cores) for longer-term incubations relative to additions of single- or double-labeled amino acids. This method has several advantages over methods that involve short-term additions of isotopically labeled single amino acids to the soil. First and most critically, labeled amino acids and other forms of organic nitrogen (including amino sugars and oligopeptides) are released from the added organic substrate and mineralized at approximately natural rates, rather than added as a pulse of a single amino acid that may or may not be large relative to truly "available" pools. The ingrowth core method therefore does not require assumptions about the relevance of such available concentrations and about whether a given amino acid is representative of other forms of organic nitrogen in the soil. Soluble nitrogen chemistry in soil may be more complicated than previously appreciated (Warren 2013) and our approach avoids these 
difficult methodological issues by allowing complex organic substrates (cyanobacterial cells) to produce isotopically labeled material at approximately natural rates and concentrations.

If organic $\mathrm{N}$ uptake varies across the growing season, depending on substrate availability, mineralization rates, and competition for uptake, our experiment and most assays of labeled $\mathrm{N}$ uptake offer a mid-season snapshot of a dynamic process. Our six-week late-summer incubations were done when both enzymatic proteolysis and $\mathrm{N}$ mineralization would be expected to be limited by the availability of labile substrate and limited at least intermittently by soil moisture, but not by temperature (Brzostek and Finzi 2011). This situation might result in strong competition by soil microbes and mycorrhizal fungi for free available organic $\mathrm{N}$ compounds. Longer incubation times could potentially provide results more representative of the full growing season. However, if the characteristic turnover time of the added organic substrate is short, the power to resolve this process would diminish with longer incubation times.

\section{Limitations}

The greatest limitation associated with the method we developed is that ingrowth cores do not perfectly represent the typical soil environment. Substantial disturbance effects may be associated with sieving roots from soil, including perhaps enhanced organic matter mineralization and altered microbial communities, and the reduced root density in the ingrowth core may increase the supply of inorganic $\mathrm{N}$ relative to plant demand. Additionally, in longer-term incubations it is necessary to account for respiration of amino acid carbon. We used a value of $50 \%$ of amino acid carbon respired when estimating organic uptake of labeled N. Along with sampling error of baseline $\delta^{13} \mathrm{C}$, this assumption is responsible for a considerable amount of uncertainty in the mean intact organic uptake at each site, but does not change our conclusions that organic uptake is at least a small and possibly significant component of the $\mathrm{N}$ budget in these temperate forest stands.

Another assumption that could cause this approach to underestimate organic $\mathrm{N}$ uptake is the assumption that the $\mathrm{N}$ transfer compound from mycorrhizal fungi to their plant host is organic. If a large portion of organic $\mathrm{N}$ taken up by mycorrhizal fungi is de-aminated and transferred as an inorganic $\mathrm{N}$ compound, then our method based on the ratio of ${ }^{13} \mathrm{C}$ excess to ${ }^{15} \mathrm{~N}$ excess in mycorrhizal fine roots will 
underestimate the level of organic uptake. The forms of $\mathrm{N}$ transferred from the mycorrhizal fungus to the plant host appear to vary; evidence supports both ammonium and organic forms such as glutamate and arginine (Chalot and Brun 1998; Govindarajulu et al. 2005; Chalot et al. 2006; Lambers et al. 2008; Jin et al. 2012). If organically acquired $\mathrm{N}$ is transferred to other amino acids for transport from the extraradical fungal structures towards the fungal/plant interface, some of the ${ }^{13} \mathrm{C}$ label will be separated from the ${ }^{15} \mathrm{~N}$ with which it was taken up. Our fine-root samples included at least some of the ectomycorrhizal mantle and intraradical arbuscular fungal structures. The removal of the majority of extraradical fungal biomass with rhizosphere soil prior to analysis may mean that the measured ${ }^{13} \mathrm{C}$ excess to ${ }^{15} \mathrm{~N}$ excess ratio underestimates the importance of organic $\mathrm{N}$ uptake by the whole mycorrhizal system, possibly by a large amount.

Calculations of $f_{\text {intact }}$ calculated from protein extracts of the roots samples was of the same general magnitude of those calculated from bulk analysis, but values were systematically greater in the bulk analysis (Fig. 2). This might relate to additional loss of fungal tissue in the additional handling of dried samples prior to protein extraction. The good match between the two methods in the oak-beech samples may mean that these samples lost more of their surface fungal tissue prior to the bulk analysis. In any case, the ability to detect enriched ${ }^{13} \mathrm{C}$ is greatly improved by isolating the non-soluble protein fraction for analysis. The consequences of measurement error in ${ }^{13} \mathrm{C}$ enrichment on the $f_{\text {intact }}$ calculation is greatest where uptake of the $\mathrm{N}$ label is lowest (Fig. 1).

\section{Improvements}

This method would be improved by reducing within-core heterogeneity of label application, perhaps by injecting the substrate when soil is at or above field capacity. The fairly dry soils we encountered when applying the label likely contributed to the observed heterogeneity. Also, grinding the root samples would lead to more representative isotope measurements - we did not do this avoid laboratory contamination with ${ }^{13} \mathrm{C}$ - and ${ }^{15} \mathrm{~N}$-enriched material. A longer root-ingrowth period prior to the addition of the labeled substrate, or using intact cores, would mitigate concerns about low root biomass in the cores and roots being less competitive with microbes than in the intact soil. A shorter incubation 
time, or a series of incubation times would provide additional information about how time factors in the proportion of the label that is taken up in inorganic form, as more of it is mineralized over time (Rothstein 2014).

\section{Comparison to other organic $N$ uptake studies}

In temperate forests, $\mathrm{N}$ mineralization frequently explains much of the observed variation in primary production (Pastor et al. 1984; Carlyle and Nambiar 2001; Newman et al. 2006), suggesting an often dominant role for inorganic $\mathrm{N}$ uptake in meeting plant $\mathrm{N}$ requirements (Wu 2011). In contrast, in colder climates where $\mathrm{N}$ mineralization is slow, plants in boreal and tundra ecosystems appear to rely heavily on organic N forms (Schimel and Chapin 1996; Näsholm et al.1998). Our temperate forest sites were selected to span a range in $\mathrm{N}$ mineralization rates, from spruce sites with recalcitrant litter and thick organic horizons to maple sites with high-quality litter and high $\mathrm{N}$ mineralization. We saw nonsignificantly greater reliance on organic $\mathrm{N}$ in the spruce sites, though the very low root production in these cores limited our ability to assess uptake.

Direct uptake experiments involving short-term isotope label uptake in comparable study systems show a similar pattern, in which sites with higher mineralization rates rely somewhat less on organic $\mathrm{N}$. Maple-ash forests in Connecticut took up relatively little labeled glycine relative to inorganic N (about $20 \%$ of total), while glycine represented $48-77 \%$ (by horizon) of total uptake in nearby hardwoodhemlock forests (Gallet-Budynek et al. 2009). Excised roots from these and a pine-dominated site took up DIN at 2-6 times the rate of glycine (Finzi and Berthrong 2005). Similarly, recovery of ${ }^{13} \mathrm{C}$ from labeled glycine indicated a higher importance of amino acid uptake in a Michigan oak stand relative to a paired maple-dominated stand with a higher mineralization rate, though \% organic uptake was not calculated (Rothstein 2014). In spruce-fir-birch forests $\sim 100 \mathrm{~km}$ north of our study area, uptake of added glycine-N increased with elevation and exceeded DIN at high elevations, where temperature presumably limited N mineralization to a greater degree (Averill and Finzi 2011). On the other hand, no evidence of intact glycine uptake was seen in either pine or maple in South Carolina, possibly due to greater P than $\mathrm{N}$ limitation in those soils (Jin et al. 2010). 
Our estimates of organic $\mathrm{N}$ uptake are generally lower than those provided by short-term labeled uptake studies in similar systems, though this might be attributable to stand-scale or temporal differences in mineralization and uptake processes. The relative uptake of labeled single amino acids and inorganic $\mathrm{N}$ over short incubation times cannot necessarily be compared to our estimates of organic and inorganic $\mathrm{N}$ uptake based on longer-term incubations of a complex organic matter substrate. Moreover, as discussed above, our estimates likely represent minimum uptake rates due primarily to the potential for retention of labeled $\mathrm{C}$ in extraradical fungal tissue. Very high amounts of label respiration would be necessary though in order to make our data consistent with the higher rates of uptake reported in some shorter-term experiments (e.g. Finzi and Berthrong 2005; Gallet-Budynek et al. 2009; Rothstein 2014). Label retention in extraradical fungal tissues (e.g., if ammonium is the predominant $\mathrm{N}$ transfer compound) would presumably mask organic uptake by mycorrhizal fungi in both long and short incubation approaches, unless the relatively high concentrations of labeled amino acids in short-term incubations drive uptake as hypothesized by Hobbie and Hobbie (2012). Given the opposing biases in each method, they may bracket a range of realistic uptake rates.

Direct methods comparisons in the same forest stands may be warranted, and could shed light on the relevance of the various assumptions required by each method. However, comparing short- and longer-term rates is inherently difficult, and may require multiple short-term measurements. The difference between adding a short-term substrate to intact soils containing high densities of live and dead roots and adding a longer-term substrate to disturbed cores with low root density must also be considered. Lateral transfer of labeled $\mathrm{N}$ from one treatment location to another nearby (as seen in the ${ }^{15} \mathrm{~N}$ enrichment of control-core roots in this study) could also confound such a comparison; the optimal spacing to take advantage of spatial autocorrelation in stand structure and soil properties but avoid isotopic transfer among treated and untreated cores is unclear.

\section{Conclusions}

We used a six-week double-labeled organic matter incubation to detect a fairly small (1-14\%) contribution of organic nitrogen uptake to mycorrhizal tree roots in four temperate forest types. This 
method allowed us to avoid some potentially problematic assumptions about available concentrations of amino acids in soil solution or the identity of quantitatively important plant-available and mycorrhizalavailable organic $\mathrm{N}$ compounds. Our estimates of organic $\mathrm{N}$ uptake are notably lower than others from similar forests, but likely understate the importance of organic $\mathrm{N}$ uptake due to transamination (separation of the ${ }^{13} \mathrm{C}$ label from the ${ }^{15} \mathrm{~N}$ label) within the part of the mycorrhizal fungus not sampled. This method confirms that the capacity for organic $\mathrm{N}$ uptake exists across temperate forest ecosystem types that include both ectomycorrhizal and arbuscular mycorrhizal tree species. Future applications of this method, perhaps in concert with shorter-term approaches and culture-based estimates of transamination, could further refine estimates of the importance of organic uptake across seasonal and successional time scales, as well as across different forest types and disturbance/management histories.

\section{Acknowledgements}

We thank R. Mixon, Z. McAvoy, N. Gagnon, and M. Day for assistance in the field and laboratory. J. Hobbie, S. Ollinger, A. Finzi, J. Aber, M. Ducey, J. Bryce, and two anonymous reviewrs provided thoughtful discussion on experimental design and helped to improve the manuscript. This work was funded by a Switzer Environmental Fellowship, a UNH Dissertation Year Fellowship, the NRESS graduate program, and NSF DEB0614266. We thank the UNH Office of Woodlands and Natural Areas, the Town of Strafford Conservation Commission, and the NH DRED Division of Forests and Lands for field site access.

\section{References}

Averill C, Finzi AC (2011) Increasing plant use of organic nitrogen with elevation is reflected in nitrogen uptake rates and ecosystem $\delta^{15} \mathrm{~N}$. Ecology 92:883-891. doi: 10.1890/10-0746.1

Averill C, Turner BL, Finzi AC (2014) Mycorrhiza-mediated competition between plants and decomposers drives soil carbon storage. Nature 505:543-545. doi: 10.1038/nature12901 
Blackburn TH, Knowles R (1992) Chapter 1. In Paul EA, Knowles R, Melillo JM, and Blackburn TH, (eds), Nitrogen Isotope Techniques. Academic Press, San Diego.

Brzostek ER, Finzi AC (2011) Substrate supply, fine roots, and temperature control proteolytic enzyme activity in temperate forest soils. Ecology 92:892-902. doi: 10.1890/10-1803.1

Carlyle JC, Nambiar EKS (2001) Relationships between net nitrogen mineralization, properties of the forest floor and mineral soil, and wood production in Pinus radiata plantations. Can J For Res 31:889-898. doi: 10.1139/x01-008

Chalot M, Blaudez D, Brun A (2006) Ammonia: a candidate for nitrogen transfer at the mycorrhizal interface. Trends Plant Sci 11:263-6. doi: 10.1016/j.tplants.2006.04.005

Chalot M, Brun A (1998) Physiology of organic nitrogen acquisition by ectomycorrhizal fungi and ectomycorrhizas. FEMS Microbiol Rev 22:21-44. doi: 10.1111/j.1574-6976.1998.tb00359.x

Chapin FS, Moilanen L, Kielland K (1993) Preferential use of organic nitrogen for growth by a nonmycorrhizal arctic sedge. Nature 361:150-153. doi: 10.1038/361150a0

Chapin FS, Neff JC, Vitousek PM (2003) Breaks in the cycle: dissolved organic nitrogen in terrestrial ecosystems. Front Ecol Environ 1:205. doi: 10.2307/3868065

Clark BR, Hartley SE, Suding KN, de Mazancourt C (2005) The effect of recycling on plant competitive hierarchies. Am Nat 165:609-622. doi: 10.1086/430074

Coplen TB (2011) Guidelines and recommended terms for expression of stable-isotope-ratio and gas-ratio measurement results. Rapid Commun Mass Spectrom 25:2538-2560. doi: 10.1002/rcm.5129

Federer CA, Turcotte DE, Smith CT (1993) The organic fraction - bulk density relationship and the expression of nutrient content in forest soils. Can J For Res 23:1026-1032. doi: 10.1139/x93-131

Finzi AC, Berthrong ST (2005) The uptake of amino acids by microbes and trees in three cold-temperate forests. Ecology 86:3345-3353. doi: 10.1890/04-1460

Gallet-Budynek A, Brzostek E, Rodgers VL, et al.(2009) Intact amino acid uptake by northern hardwood and conifer trees. Oecologia 160:129-138. doi: 10.1007/s00442-009-1284-2 
Govindarajulu M, Pfeffer PE, Jin H, et al. (2005) Nitrogen transfer in the arbuscular mycorrhizal symbiosis. Nature 435:819-823. doi: 10.1038/nature03610

Harpole WS, Ngai JT, Cleland EE, et al. (2011) Nutrient co-limitation of primary producer communities. Ecol Lett 14:852-62. doi: 10.1111/j.1461-0248.2011.01651.x

Hill PW, Farrar J, Roberts P, et al. (2011a) Vascular plant success in a warming Antarctic may be due to efficient nitrogen acquisition. Nat Clim Chang 1:50-53. doi: 10.1038/nclimate1060

Hill PW, Quilliam RS, DeLuca TH, et al. (2011b) Acquisition and assimilation of nitrogen as peptidebound and D-enantiomers of amino acids by wheat. PLoS One 6:e19220. doi: 10.1371/journal.pone.0019220

Hobbie EA, Ouimette AP, Schuur EAG, et al. (2013) Radiocarbon evidence for the mining of organic nitrogen from soil by mycorrhizal fungi. Biogeochemistry 114:381-389. doi: 10.1007/s10533-0129779-Z

Hobbie EA, Sánchez FS, Rygiewicz PT (2012) Controls of isotopic patterns in saprotrophic and ectomycorrhizal fungi. Soil Biol Biochem 48:60-68. doi: 10.1016/j.soilbio.2012.01.014

Hobbie JE, Hobbie EA (2012) Amino acid cycling in plankton and soil microbes studied with radioisotopes: measured amino acids in soil do not reflect bioavailability. Biogeochemistry 107:339-360. doi: 10.1007/s10533-010-9556-9

Hobbie JE, Hobbie EA (2013) Microbes in nature are limited by carbon and energy: The starving-survival lifestyle in soil and consequences for estimating microbial rates. Front Microbiol 4:324. doi: $10.3389 /$ fmicb.2013.00324

Högberg P, Högbom L, Schinkel H, et al. (1996) ${ }^{15} \mathrm{~N}$ abundance of surface soils, roots and mycorrhizas in profiles of European forest soils. Oecologia 108:207-214. doi: 10.1007/BF00334643

Inselsbacher E, Näsholm T (2012) The below-ground perspective of forest plants: soil provides mainly organic nitrogen for plants and mycorrhizal fungi. New Phytol 195:329-334. doi: 10.1111/j.14698137.2012.04169.x 
Jacob A, Leuschner C (2015) Complementarity in the use of nitrogen forms in a temperate broad-leaved mixed forest. Plant Ecol Divers 8:243-258. doi: 10.1080/17550874.2014.898166

Jin H, Liu J, Liu J, Huang X (2012) Forms of nitrogen uptake, translocation, and transfer via arbuscular mycorrhizal fungi: a review. Sci China Life Sci 55:474-82. doi: 10.1007/s11427-012-4330-y

Jin VL, Romanek CS, Donovan LA, Sharitz RR (2010) Soil nitrogen availability and in situ nitrogen uptake by Acer rubrum L . and Pinus palustris Mill in the southeastern US coastal plain. J Torrey Bot Soc 137:339-347. doi: 10.3159/10-RA-022.1

Jones DL, Healey JR, Willett VB, et al. (2005a) Dissolved organic nitrogen uptake by plants - an important N uptake pathway? Soil Biol Biochem 37:413-423. doi: 10.1016/j.soilbio.2004.08.008

Jones DL, Shannon D, Junvee-Fortune T, Farrar JF (2005b) Plant capture of free amino acids is maximized under high soil amino acid concentrations. Soil Biol Biochem 37:179-181. doi: 10.1016/j.soilbio.2004.07.021

Kirkham D, Bartholomew W (1954) Equations for following nutrient transformations in soil, utilizing tracer data. Soil Sci Soc Am J 18:33-34. doi: 10.2136/sssaj1954.03615995001800010009x

Lambers H, Raven JA, Shaver GR, Smith SE (2008) Plant nutrient-acquisition strategies change with soil age. Trends Ecol Evol 23:95-103. doi: 10.1016/j.tree.2007.10.008

LeBauer DS, Treseder KK (2008) Nitrogen limitation of net primary productivity in terrestrial ecosystems is globally distributed. Ecology 89:371-379. doi: 10.1890/06-2057.1

Lipson DA, Näsholm T (2001) The unexpected versatility of plants: organic nitrogen use and availability in terrestrial ecosystems. Oecologia 128:305-316. doi: 10.1007/s004420100693

Lipson DA, Raab TK, Schmidt SK, Monson RK (1999) Variation in competitive abilities of plants and microbes for specific amino acids. Biol Fertil Soils 29:257-261. doi: 10.1007/s003740050550

Mayor JR, Schuur EAG, Mack MC, et al. (2012) Nitrogen isotope patterns in Alaskan black spruce reflect organic nitrogen sources and the activity of ectomycorrhizal fungi. Ecosystems 15:819-831. doi: $10.1007 / \mathrm{s} 10021-012-9548-9$ 
McKane RB, Johnson LC, Shaver GR, et al. (2002) Resource-based niches provide a basis for plant species diversity and dominance in arctic tundra. Nature 415:68-71. doi: 10.1038/415068a

Näsholm T, Ekblad A, Nordin A, et al. (1998) Boreal forest plants take up organic nitrogen. Nature 392:914-916. doi: 10.1038/31921

Näsholm T, Kielland K, Ganeteg U (2009) Uptake of organic nitrogen by plants. New Phytol 182:31-48. doi: 10.1111/j.1469-8137.2008.02751.x

Newman GS, Arthur MA, Muller RN (2006) Above- and belowground net primary production in a temperate mixed deciduous forest. Ecosystems 9:317-329. doi: 10.1007/s10021-006-0015-3

Orwin KH, Kirschbaum MUF, St. John MG, Dickie IA (2011) Organic nutrient uptake by mycorrhizal fungi enhances ecosystem carbon storage: a model-based assessment. Ecol Lett 14:493-502. doi: 10.1111/j.1461-0248.2011.01611.x

Ouimette A, Guo D, Hobbie E, Gu J (2012) Insights into root growth, function, and mycorrhizal abundance from chemical and isotopic data across root orders. Plant Soil 367:313-326. doi: $10.1007 / \mathrm{s} 11104-012-1464-4$

Pastor J, Aber JD, Mcclaugherty CA, Melillo JM (1984) Aboveground production and N and P cycling along a nitrogen mineralization gradient on Blackhawk Island, Wisconsin. Ecology 65:256-268. doi: $10.2307 / 1939478$

Paungfoo-Lonhienne C, Lonhienne TGA, Rentsch D, et al. (2008) Plants can use protein as a nitrogen source without assistance from other organisms. Proc Natl Acad Sci U S A 105:4524-4529. doi: 10.1073/pnas.0712078105

Persson J, Högberg P, Ekblad A, et al. (2003) Nitrogen acquisition from inorganic and organic sources by boreal forest plants in the field. Oecologia 137:252-7. doi: 10.1007/s00442-003-1334-0

Rothstein DE (2014) In-situ root uptake and soil transformations of glycine, glutamine and ammonium in two temperate deciduous forests of contrasting N availability. Soil Biol Biochem 75:233-236. doi: 10.1016/j.soilbio.2014.04.004 
Schimel JP, Chapin FS (1996) Tundra plant uptake of amino acid and NH4+ nitrogen in situ: plants complete well for amino acid N. Ecology 77:2142-2147. doi: 10.2307/2265708

Stribley DP, Read DJ (1980) The biology of mycorrhiza in the Ericaceae VII. The relationship between mycorrhizal infection and the capacity to utilize simple and complex organic nitrogen sources. New Phytol 86:365-371.

Vadeboncoeur MA (2010) Meta-analysis of fertilization experiments indicates multiple limiting nutrients in northeastern deciduous forests. Can J For Res 40:1766-1780. doi: 10.1139/X10-127

Vadeboncoeur MA (2013) Mechanisms of nutrient limitation and nutrient acquisition in managed and unmanaged forest ecosystems. Ph.D. Dissertation. Univ. New Hampshire. http://scholars.unh.edu/dissertation/1/

Warren CR (2013) High diversity of soil organic N observed in soil water. Soil Biol Biochem 57:444450. doi: 10.1016/j.soilbio.2012.09.025

Whiteside MD, Digman MA, Gratton E, Treseder KK (2012) Organic nitrogen uptake by arbuscular mycorrhizal fungi in a boreal forest. Soil Biol Biochem 55:7-13. doi: 10.1016/j.soilbio.2012.06.001

Wu T (2011) Can ectomycorrhizal fungi circumvent the nitrogen mineralization for plant nutrition in temperate forest ecosystems? Soil Biol Biochem 43:1109-1117. doi: 10.1016/j.soilbio.2011.02.003

Wurzburger N, Hendrick RL (2009) Plant litter chemistry and mycorrhizal roots promote a nitrogen feedback in a temperate forest. J Ecol 97:528-536. doi: 10.1111/j.1365-2745.2009.01487.x

Xu X, Ouyang H, Kuzyakov Y, et al. (2006) Significance of organic nitrogen acquisition for dominant plant species in an alpine meadow on the Tibet plateau, China. Plant Soil 285:221-231. doi: 10.1007/s11104-006-9007-5

Yanai RD, Levine CR, Green MB, Campbell JL (2012) Quantifying uncertainty in forest nutrient budgets. J For 110:448-456. doi: 10.5849/jof.11-087 


\section{Table 1}

Study site description and characteristics of soil used to fill ingrowth cores. Sites are ordered geographically from south to north. Lat=latitude and Lon= longitude. Soil characteristics are the means of 3 analyses per site. Mineralization is based on a 31-day lab incubation.

\begin{tabular}{|c|c|c|c|c|c|c|c|c|c|c|c|c|c|c|}
\hline Site & Name & $\begin{array}{l}\text { Forest } \\
\text { type }\end{array}$ & Lat & Lon & $\begin{array}{c}\text { Elev } \\
(\mathrm{m})\end{array}$ & Aspect & Slope & $\begin{array}{l}\text { Soil } \\
\% \mathrm{C} \\
\end{array}$ & $\begin{array}{l}\text { Soil } \\
\text { C:N } \\
\end{array}$ & $\begin{array}{c}\text { Bulk } \\
\text { density } \\
\left(\mathrm{g} \mathrm{cm}^{-3}\right) \\
\end{array}$ & $\begin{array}{l}\text { Soil } \\
\delta^{15} \mathrm{~N} \\
(\%) \\
\end{array}$ & $\mathrm{pH}$ & $\begin{array}{c}\text { Exch. } \\
\mathrm{NH}_{4} \\
\left(\mu \mathrm{g} \mathrm{N} \mathrm{g}^{-1}\right) \\
\end{array}$ & $\begin{array}{c}\text { mineralization } \\
\text { + nitrification } \\
\left(\mu \mathrm{g} \mathrm{N} \mathrm{g}^{-1} \text { soil }\right)\end{array}$ \\
\hline DP & Davis Park & maple & 43.10 & -70.98 & 30 & flat & $<5 \%$ & 10.7 & 15.5 & 0.41 & 1.8 & 5.0 & 94.8 & 34.6 \\
\hline $\mathbf{C W}$ & College Woods & pine & 43.13 & -70.95 & 20 & S & $5-10 \%$ & 10.8 & 24.7 & 0.40 & 1.8 & 4.4 & 40.6 & 9.7 \\
\hline KF & Kingman Farm & oak-beech & 43.18 & -70.93 & 40 & W & $5-10 \%$ & 6.2 & 22.3 & 0.58 & 3.6 & 4.4 & 25.1 & 7.0 \\
\hline PS & Parker Mtn - upper & spruce & 43.29 & -71.16 & 400 & $\mathrm{E}$ & $<5 \%$ & 19.3 & 32.8 & 0.26 & 0.8 & 3.6 & 45.6 & 17.3 \\
\hline PO & Parker Mtn - lower & oak-beech & 43.29 & -71.16 & 390 & $\mathrm{E}$ & $30-40 \%$ & 9.7 & 25.8 & 0.43 & 4.3 & 4.5 & 27.3 & 38.9 \\
\hline BJ & Blue Job Mtn & spruce & 43.33 & -71.12 & 370 & W & $15-50 \%$ & 18.0 & 27.3 & 0.27 & 0.3 & 3.5 & 80.0 & 6.2 \\
\hline JP & Jones Prop. - lower & pine & 43.47 & -71.01 & 170 & $\mathrm{E}$ & $5-15 \%$ & 8.0 & 21.4 & 0.49 & 4.1 & 5.1 & 57.1 & 1.7 \\
\hline JM & Jones Prop. - upper & maple & 43.48 & -71.01 & 180 & $\mathrm{NE}$ & $0-30 \%$ & 10.5 & 18.2 & 0.41 & 3.7 & 5.2 & 75.3 & 36.2 \\
\hline
\end{tabular}




\section{Table 2}

Mass and stable isotope ratios from roots harvested after approximately 10 weeks of ingrowth, including 6 weeks with incubating tracer additions in the treatment cores. Values are means $1 \pm$ SD.

\begin{tabular}{lllll} 
& $\begin{array}{l}\text { mean target } \\
\text { root mass } \\
\text { per core }(\mathrm{mg})\end{array}$ & $\begin{array}{l}\text { control } \\
\text { root } \\
\delta^{13} \mathrm{C}(\%)\end{array}$ & $\begin{array}{l}\text { treatment } \\
\text { root } \\
\delta^{13} \mathrm{C}(\%)\end{array}$ & $\begin{array}{l}\text { treatment } \\
\text { root } \\
\delta^{15} \mathrm{~N}(\%)\end{array}$ \\
\hline Site (type) & $30.8 \pm 40.8$ & $-27.6 \pm 1.2$ & $-18.3 \pm 6.8$ & $16100 \pm 11600$ \\
DP (maple) & $6.8 \pm 4.5$ & $-26.5 \pm 0.8$ & $-23.8 \pm 2.2$ & $1760 \pm 1500$ \\
CW (pine) & $39.1 \pm 21.4$ & $-28.1 \pm 0.9$ & $-25.1 \pm 3.1$ & $2890 \pm 1880$ \\
KF (oak-beech) & $8.1 \pm 5.0$ & $-26.8 \pm 1.1$ & $-21.9 \pm 3.3$ & $5110 \pm 5660$ \\
PS (spruce) & $42.7 \pm 16.1$ & $-27.8 \pm 0.9$ & $-25.2 \pm 3.5$ & $6470 \pm 6050$ \\
PO (oak-beech) & $2.1 \pm 2.2$ & $-26.5 \pm 0.6$ & $-21.1 \pm 6.3$ & $3785 \pm 5510$ \\
BJ (spruce) & $9.7 \pm 6.0$ & $-27.6 \pm 0.9$ & $-27.5 \pm 1.5$ & $910 \pm 790$ \\
JP (pine) & $18.9 \pm 19.0$ & $-28.0 \pm 1.3$ & $-24.7 \pm 1.7$ & $1660 \pm 1040$ \\
JM (maple) & & & &
\end{tabular}


Figure 1. Scatter plot of protein ${ }^{13} \mathrm{C}$ excess (estimated from bulk analysis) and bulk ${ }^{15} \mathrm{~N}$ excess. Straight lines show ${ }^{13} \mathrm{C}_{\text {excess }}:{ }^{15} \mathrm{~N}_{\text {excess }}$ ratios that correspond to a range of values for the percentage of labeled nitrogen taken up in organic form $\left(f_{\text {intact }}\right)$. Replicate analyses of root samples are plotted independently here, but are averaged in subsequent figures. Symbols indicate stand type. Uncertainty in protein ${ }^{13} \mathrm{C}_{\text {excess }}$ $( \pm 2 \mathrm{SD})$ is shown as error bars for four representative data points.

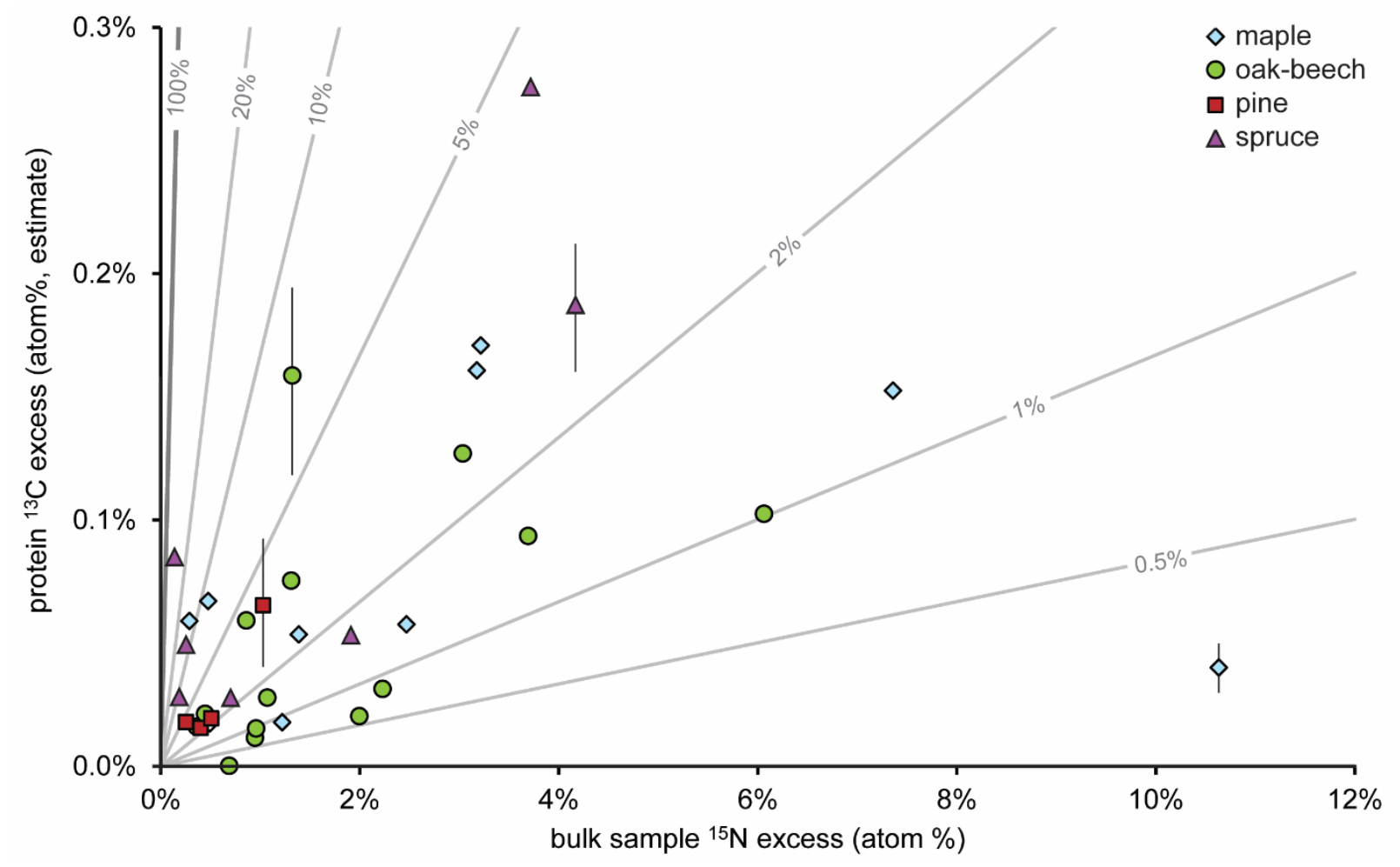


Figure 2. Organic $\mathrm{N}$ uptake estimated from amino acid vs. bulk root analyses. The solid line shows the expected 1:1 relationship. Oak-beech samples show good agreement between the two methods, but overall bulk analyses yielded significantly greater estimates of organic $\mathrm{N}$ uptake than amino acid analyses. This could be due to sample heterogeneity, surface contamination of the bulk samples, or fungal tissue that was lost in the extra processing steps prior to amino acid extraction.

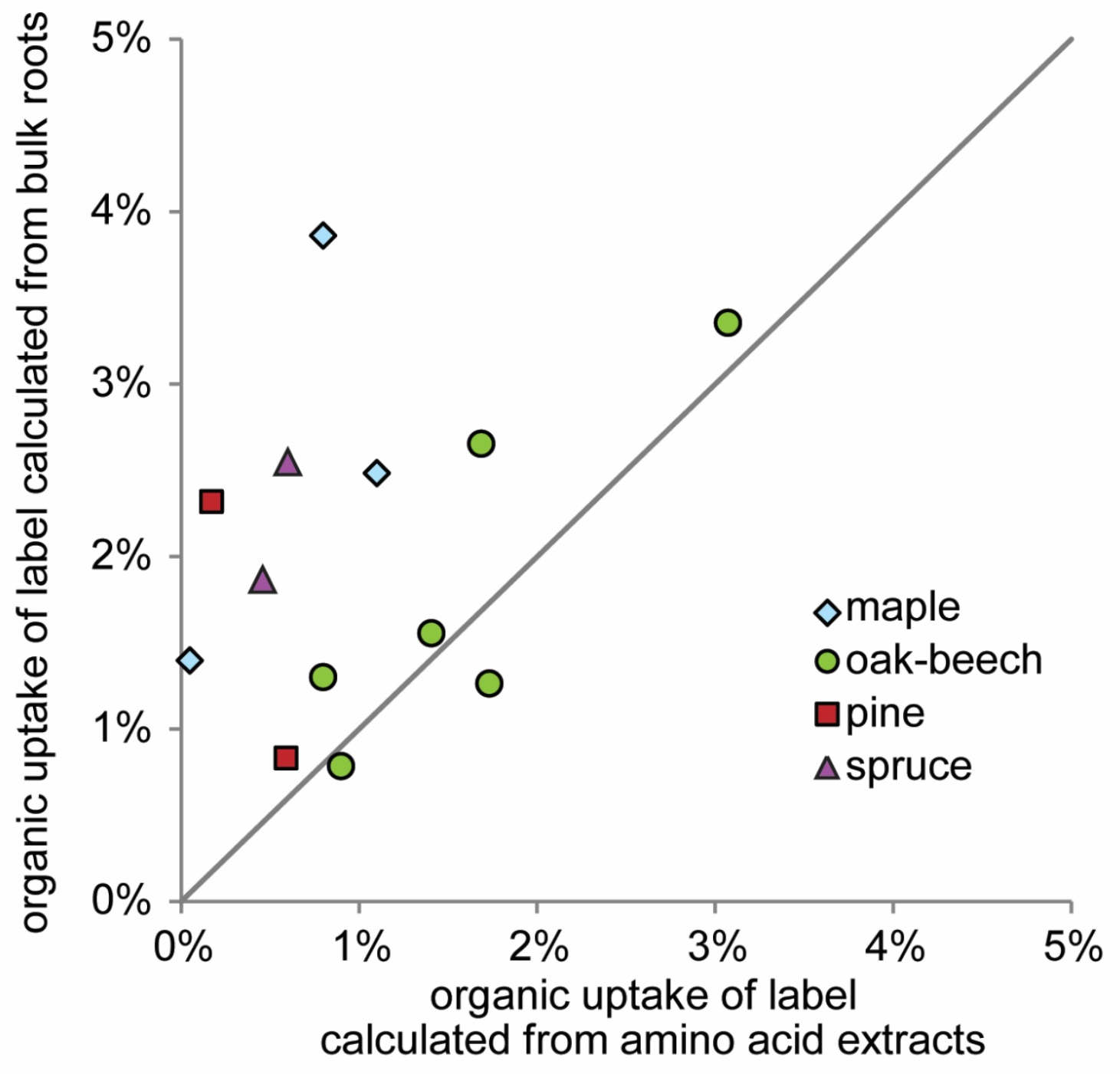


Figure 3. Magnitude of sources of uncertainty in estimating intact uptake of the organic $\mathrm{N}$ tracer. Each boxplot shows the median, first and third quartiles, and 95\% envelope from a 10,000 iteration Monte Carlo analysis where baseline $\delta^{13} \mathrm{C}$ varied with a normal distribution based on multiple analyses of control roots at each site, and amino acid C respiration varied with a uniform distribution between $25 \%$ and $75 \%$. The uncertainty in organic uptake derived from uncertainty in these values was usually greater than the range of variation among the three replicate cores at each site, which is represented by the lightly shaded region around each boxplot.

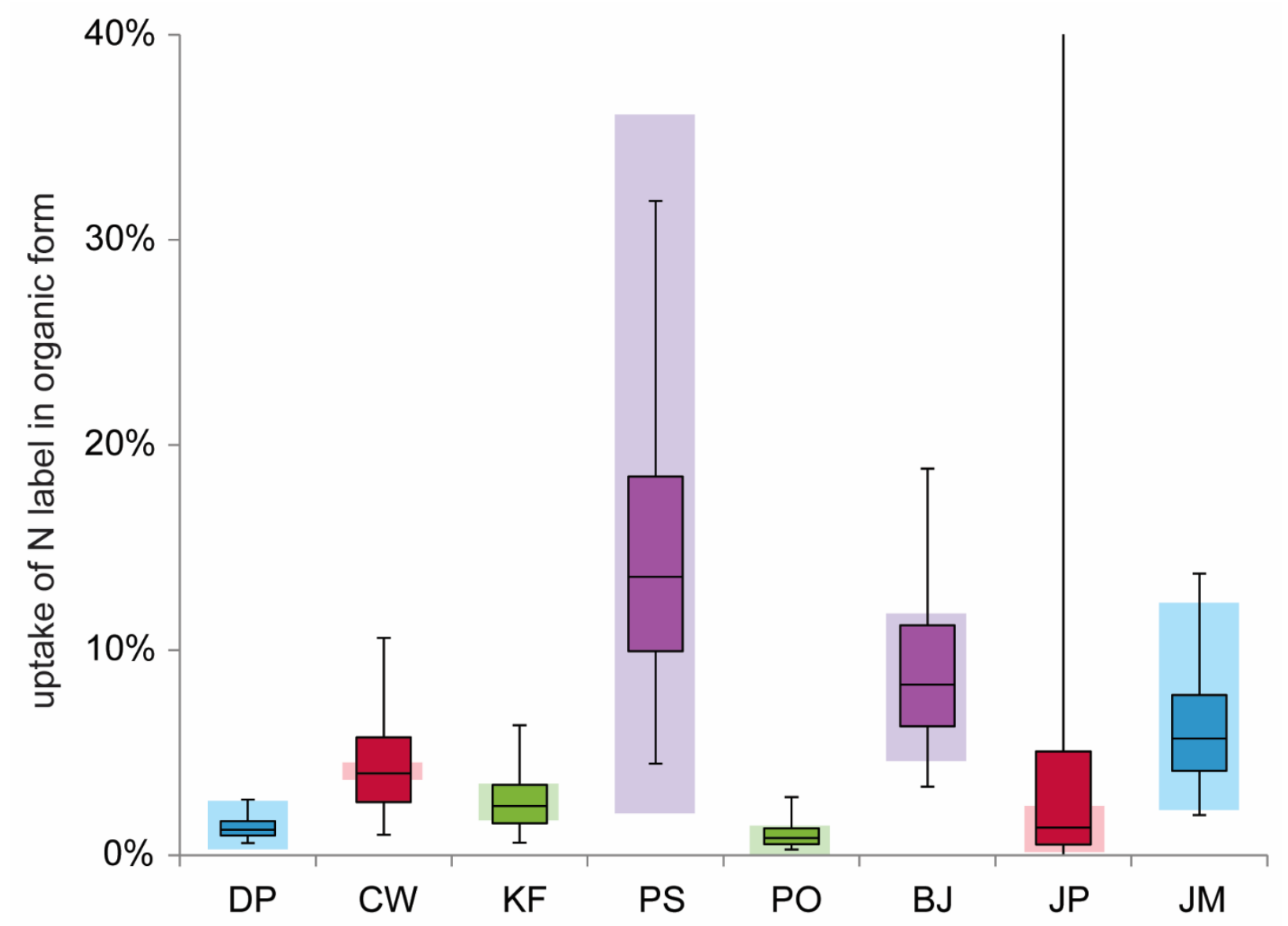




\section{Supplemental Material: Calculating the uptake of labeled organic $\mathbf{N}$}

All isotope data were converted to atom fraction for isotope excess calculations. Notation follows Coplen (2011). "ON" indicates roots from cores with the isotopically labeled organic substrate.

Excess atom fraction of ${ }^{15} \mathrm{~N}$ and ${ }^{13} \mathrm{C}$ in $\mathrm{ON}$ treatment root amino acid extracts were calculated as:

$$
\begin{aligned}
& x^{E}\left({ }^{15} \mathrm{~N}\right)_{O N}=x_{A A}\left({ }^{15} \mathrm{~N}\right)-x_{\text {control soil }}\left({ }^{15} \mathrm{~N}\right) \\
& x^{E}\left({ }^{13} \mathrm{C}\right)_{O N}=x_{A A}\left({ }^{13} \mathrm{C}\right)-x_{\text {control roots }}\left({ }^{13} \mathrm{C}\right)
\end{aligned}
$$

Excess atom fraction of ${ }^{15} \mathrm{~N}$ was calculated in the same way from bulk root analyses, based on the assumption that non-protein $\mathrm{N}$ was negligible in bulk roots:

$$
x^{E}\left({ }^{15} \mathrm{~N}\right)_{O N}=x_{\text {root }}\left({ }^{15} \mathrm{~N}\right)-x_{\text {control soil }}\left({ }^{15} \mathrm{~N}\right)
$$

Excess atom fraction of ${ }^{13} \mathrm{C}$ in root protein was calculated from bulk root analyses with a mixing equation:

$$
x^{E}\left({ }^{13} \mathrm{C}\right)_{O N}=\frac{x_{\text {bulk }}\left({ }^{13} \mathrm{C}\right)-x_{\text {baseline }}\left({ }^{13} \mathrm{C}\right) \times\left(1-f_{A A}\right)}{f_{A A}}-x_{\text {baseline }}\left({ }^{13} \mathrm{C}\right)
$$

where $f_{\mathrm{AA}}$, the fraction of root $\mathrm{C}$ in amino acids, is estimated as:

$$
f_{A A}=\frac{2.86 \times[N]_{\text {root }}}{[C]_{\text {root }}}
$$

assuming a C:N mass ratio of 2.86 in protein (Hobbie et al., 2012)

$$
x_{\text {baseline }}\left({ }^{13} \mathrm{C}\right)=x_{\text {control root }}\left({ }^{13} \mathrm{C}\right)+0.0000234
$$

based on the ${ }^{13} \mathrm{C}$ offset between proteins and bulk analyses of archived fine roots.

Finally, intact organic $\mathrm{N}$ uptake as a fraction of total $\mathrm{N}$ uptake was calculated as:

$$
f_{\text {intact }}=\frac{x^{E}\left({ }^{13} \mathrm{C}\right)_{O N}}{0.5 \times 3.34 \times x^{E}\left({ }^{15} \mathrm{~N}\right)_{O N}}
$$

assuming a C:N mole ratio of 3.34 in protein (Hobbie et al., 2012), and that half of protein-C is respired (Hobbie and Hobbie, 2012). One ON root sample (from site JP) was more depleted in ${ }^{13} \mathrm{C}$ than the control roots in two replicate analyses. This sample was assigned an organic uptake value of 0 . 